AperTO - Archivio Istituzionale Open Access dell'Università di Torino

\title{
Long-Term Clinical Outcomes of Hematopoietic Stem Cell Transplantation in Multiple Sclerosis
}

\section{This is the author's manuscript}

Original Citation:

Availability:

This version is available http://hdl.handle.net/2318/1770694

since 2021-02-01T18:18:39Z

Published version:

DOI:10.1212/WNL.0000000000011461

Terms of use:

Open Access

Anyone can freely access the full text of works made available as "Open Access". Works made available under a Creative Commons license can be used according to the terms and conditions of said license. Use of all other works requires consent of the right holder (author or publisher) if not exempted from copyright protection by the applicable law. 


\title{
Long-Term Clinical Outcomes of Hematopoietic Stem Cell Transplantation in Multiple Sclerosis
}

\author{
Author(s): \\ Giacomo Boffa, MD; Luca Massacesi, MD; Matilde Inglese, MD, PhD; Alice Mariottini, MD; Marco Capobianco, \\ MD; Moiola Lucia, MD; Maria Pia Amato, MD; Salvatore Cottone, MD; Francesca Gualandi, MD; Marco De \\ Gobbi, MD; Raffaella Greco, MD; Rosanna Scimè, MD; Jessica Frau, MD; Giovanni Bosco Zimatore, MD; Antonio \\ Bertolotto, MD; Giancarlo Comi, MD; Antonio Uccelli, MD; Alessio Signori, PhD; Emanuele Angelucci, MD; \\ Chiara Innocenti, MD; Fabio Ciceri, MD; Anna Maria Repice, MD; Maria Pia Sormani, PhD; Riccardo Saccardi, \\ MD; Gianluigi Mancardi, MD on behalf of the Italian BMT-MS study group
}

\section{Corresponding Author:}

Matilde Inglese

m.inglese@unige.it

Affiliation Information for All Authors: Giacomo Boffa, Department of Neurology, Rehabilitation, Ophthalmology, Genetics, Maternal and Child Health, University of Genoa, San Martino Hospital, Genoa/Italy; Luca Massacesi Department of Neurosciences Drugs and Child Health and Department of Neurology 2, Careggi University Hospital, Florence, Italy; Matilde Inglese Department of Neurology, Rehabilitation, Ophthalmology, Genetics, Maternal and Child Health, University of Genoa and Ospedale Policlinico San Martino, IRCCS, Genoa, Italy; Alice Mariottini Department of Neurosciences Drugs and Child Health and Department of Neurology 2, Careggi University Hospital, Florence, Italy; Marco Capobianco Department of Neurology, San Luigi Gonzaga Hospital, Orbassano, Italy; Lucia Moiola Department of Neurology, Vita-Salute San Raffaele University, San Raffaele Scientific Institute, Milan/Italy; Maria Pia Amato Department NEUROFARBA, Section Neurological Sciences University of Florence IRCCS Fondazione Don Carlo Gnocchi, Florence, Italy; Salvatore Cottone Department of Neurology, Villa Sofia Hospital, Palermo/Italy; Francesca Gualandi Department of Haematology and Bone Marrow Transplant Unit, Policlinico San Martino IRCCS, Genoa/Italy; Marco De Gobbi Department of Clinical and Biological Sciences, Haematopoietic Stem Cell Transplant Unit, University of Turin, San Luigi Gonzaga Hospital, Orbassano/Italy; Raffaella Greco Department of Haematology and Bone marrow transplant, VitaSalute San Raffaele University, San Raffaele Scientific Institute, Milan/Italy; Rosanna Scimè Department of Haematology, Villa Sofia Hospital, Palermo/Italy; Jessica Frau Multiple Sclerosis Center, Department of Medical Sciences and Public Health University of Cagliari,Binaghi Hospital Cagliari/Italy; Giovanni Bosco Zimatore Department of Neurology, Ospedale Generale Regionale "F. Miulli", Acquaviva delle Fonti, BA, Italy; Antonio Bertolotto Department of Neurology, San Luigi Gonzaga Hospital, Orbassano, Italy; Giancarlo Comi Department of Neurology, Vita-Salute San Raffaele University, San Raffaele Scientific Institute, Milan/Italy; Antonio Uccelli Department of Neurology, Rehabilitation, Ophthalmology, Genetics, Maternal and Child Health, University of Genoa and Ospedale Policlinico San Martino, IRCCS, Genoa, Italy; Alessio Signori Biostatistics Unit, University of Genoa, Genoa/Italy; Emanuele Angelucci Department of Haematology and Bone Marrow Transplant Unit, Policlinico San Martino IRCCS, Genoa/Italy; Chiara Innocenti Cell Therapy and Transfusion Medicine Unit, Careggi University Hospital, Florence/Italy; Fabio Ciceri Department of Haematology and Bone marrow transplant, Vita-Salute San Raffaele University, San Raffaele Scientific Institute, Milan/Italy; Anna Maria Repice Department of Neurosciences Drugs and Child Health and Department of Neurology 2, Careggi University Hospital, Florence, Italy; Maria Pia Sormani Biostatistics Unit, University of Genoa, Genoa/Italy; Riccardo Saccardi Cell Therapy and Transfusion Medicine Unit, Careggi University Hospital, Florence/Italy; Gianluigi Mancardi Department of Neurology, Rehabilitation, Ophthalmology, Genetics, Maternal and Child Health, University of Genoa and Ospedale Policlinico San Martino, IRCCS, Genoa, Italy and IRCCS Scientific Clinical Institutes Maugeri, Pavia-Genoa 
Nervi/Italy.

\section{Contributions:}

Giacomo Boffa: Drafting/revision of the manuscript for content, including medical writing for content; Major role in the acquisition of data; Study concept or design; Analysis or interpretation of data

Luca Massacesi: Drafting/revision of the manuscript for content, including medical writing for content; Major role in the acquisition of data

Matilde Inglese: Drafting/revision of the manuscript for content, including medical writing for content; Study concept or design; Analysis or interpretation of data

Alice Mariottini: Major role in the acquisition of data

Marco Capobianco: Major role in the acquisition of data

Moiola Lucia: Drafting/revision of the manuscript for content, including medical writing for content; Major role in the acquisition of data

Maria Pia Amato: Drafting/revision of the manuscript for content, including medical writing for content; Major role in the acquisition of data

Salvatore Cottone: Major role in the acquisition of data

Francesca Gualandi: Major role in the acquisition of data

Marco De Gobbi: Drafting/revision of the manuscript for content, including medical writing for content; Major role in the acquisition of data

Raffaella Greco: Drafting/revision of the manuscript for content, including medical writing for content; Major role in the acquisition of data

Rosanna Scimè: Major role in the acquisition of data

Jessica Frau: Major role in the acquisition of data

Giovanni Bosco Zimatore: Major role in the acquisition of data

Antonio Bertolotto: Major role in the acquisition of data

Giancarlo Comi: Drafting/revision of the manuscript for content, including medical writing for content; Major role in the acquisition of data

Antonio Uccelli: Drafting/revision of the manuscript for content, including medical writing for content; Major role in the acquisition of data

Alessio Signori: Analysis or interpretation of data

Emanuele Angelucci: Drafting/revision of the manuscript for content, including medical writing for content; Major role in the acquisition of data

Chiara Innocenti: Major role in the acquisition of data

Fabio Ciceri: Drafting/revision of the manuscript for content, including medical writing for content; Major role in the 
acquisition of data

Anna Maria Repice: Major role in the acquisition of data

Maria Pia Sormani: Drafting/revision of the manuscript for content, including medical writing for content; Analysis or interpretation of data

Riccardo Saccardi: Drafting/revision of the manuscript for content, including medical writing for content; Major role in the acquisition of data

Gianluigi Mancardi: Drafting/revision of the manuscript for content, including medical writing for content; Major role in the acquisition of data; Study concept or design; Analysis or interpretation of data

Number of characters in title: 92

Abstract Word count: 235

Word count of main text: 3479

References: 32

Figures: 3

Tables: 3

Statistical Analysis performed by: Alessio Signori, PhD Maria Pia Sormani, PhD Biostatistics Unit, University of Genoa, Genoa/Italy

Search Terms: [ 23 ] Clinical trials Observational study (Cohort, Case control), [ 41 ] Multiple sclerosis, [ 131 ] All Immunology

The authors report no targeted funding

Disclosures: Dr. Giacomo Boffa has nothing to disclose. Dr. L. Massacesi received educational grants and/or research funds from Fondazione Cassa di Risparmio di Firenze, Biogen, Merck-Serono, Genzyme, Roche; received honoraria or consultation fees from Biogen, Roche, Mylan, Merck-Serono, Genzyme, Novartis. Dr. M. Inglese received grants NIH, NMSS, FISM; received fees for consultation from Roche, Genzyme, Merck, Biogen and Novartis. Dr. A. Mariottini has nothing to disclose. Dr. M. Capobianco received personal compensation for speaking honoraria or partecipating in advisory board from Almirall, Biogen, Merck, Novartis, Roche, Sanofy, Teva. Dr. L. Moiola received personal compensation for consulting, serving on a scientific advisory board, speaking, or other activities with Sanofi-Genzyme, Novartis, Teva, Merck-Serono, Biogen, Roche, Excemed. Dr. Amato received research grants and honoraria as a speaker and member of advisory boards by Bayer, Biogen, Merck, Novartis, Sanofi Genzyme, Teva, Almirall, Roche. Dr. S. Cottone has nothing to disclose. Dr. F. Gualandi has nothing to disclose. Dr. De Gobbi M has nothing to disclose. Dr. R. Greco has nothing to disclose. Dr. R. Scimè has nothing to disclose. Dr. J Frau serves on scientific advisory boards for Biogen, received honoraria for speaking from Merck Serono, Biogen and Teva and received research grant from Serono. Dr. G.B. Zimatore has nothing to disclose. Dr. Bertolotto received honoraria for serving on the scientific advisory boards of Biogen, Merck, Mylan, and Sanofi Genzyme, and received speaker honoraria from Biogen, Genzyme, Novartis, and TEVA. Dr. G. Comi received consulting fees from Actelion, Bayer, Merck Serono, Novartis, Sanofi, and Teva and lecture fees from Bayer, Biogen Dompé, Merck Serono, Novartis, Sanofi, Serono, Symposia International Foundation, and Teva. Dr. A. Uccelli received grants and contracts from FISM, Novartis, Fondazione Cariplo, Italian Ministry of Health; received honoraria or consultation fees from Biogen, Roche, Teva, Merck, Genzyme, Novartis. Dr. A. Signori has nothing to disclose. Dr. E. Angelucci received honoraria from Novartis and Celgene, Jazz Pharmaceuticals and Roche for involvement in local advisory boards and participation in DMC for Celgene and Vertex Pharmaceuticals Incorporated and CRISPR Therapeutics. Dr. C. Innocenti has nothing to disclose. Dr. F. Ciceri has nothing to disclose. Dr. Repice has received personal compensation from Biogen Idec, Genzyme, Novartis and Merck Serono for public speaking and advisory boards. Dr. Sormani received consulting fees from Biogen Idec, Merck Serono, Teva, Genzyme, Roche, Novartis, GeNeuro and Medday. Dr. R. Saccardi reports honoraria from Jazz Pharmaceuticals and Sanofi Genzyme. Dr. G.L. Mancardi received support from Biogen Idec (honoraria for lecturing, travel expenses for attending meetings and financial support for research), Genzyme (honorarium for lecturing), Merck Serono, Novartis, Teva (financial support for research) and Sanofi Aventis (honorarium for speaking). 


\section{Abstract}

2 Objective: To determine whether autologous hematopoietic stem cell transplantation (aHSCT) is 3 able to induce durable disease remission in people with multiple sclerosis (MS), we analyzed the 4 long-term outcomes after transplant in a large cohort of MS patients.

5 Methods: To be included, a minimum data set (consisting of age, MS phenotype, EDSS at baseline,

6 information on transplant technology and at least 1 follow-up visit after transplant) was required.

7 Results: 210 patients were included [relapsing-remitting (RR)MS=122(58\%)]. Median baseline

8 EDSS was 6(1-9), mean follow-up was 6.2( \pm 5.0$)$ years. Among RRMS patients, disability

9 worsening-free survival (95\%CI) was $85.5 \%(76.9-94.1 \%)$ at 5 years and $71.3 \%(57.8-84.8 \%)$ at 10

10 years. In patients with progressive MS, disability worsening-free survival was $71.0 \%(59.4-82.6 \%)$

11 and $57.2 \%(41.8-72.7 \%)$ at 5 and 10 years, respectively. In RRMS patients, EDSS significantly

12 reduced after aHSCT $[\mathrm{p}=0.001$; mean EDSS change per year -0.09 (95\% CI=-0.15 to $-0.04 \%)$. In

13 RRMS patients, the use of the BEAM+ATG conditioning protocol was independently associated

14 with a reduced risk of NEDA-3 failure $[\mathrm{HR}=0.27(0.14-0.50), \mathrm{p}<0.001]$. Three patients died within

15 100-days from aHSCT (1.4\%); no deaths occurred in patients transplanted after 2007.

16 Conclusions: aHSCT prevents disability worsening in the majority of patients and induces durable

17 improvement in disability in patients with RRMS. The BEAM+ATG conditioning protocol is 18 associated with a more pronounced suppression of clinical relapses and MRI inflammatory activity.

19 Classification of Evidence: This study provides Class IV evidence that for people with MS, 20 aHSCT induces durable disease remission in most patients. 
28 Several disease modifying therapies have been shown to reduce disease activity in people with multiple sclerosis (MS). However long-term disease remission remains elusive ${ }^{1}$ and approved therapies have not demonstrated consistent effects in preventing long-term disability progression.

Despite treatment, more than half of relapsing-onset MS patients accumulate disability over 10 years $^{2}$. The early abrogation of relapses and MRI inflammatory activity has little impact on

33 neurological outcomes at 10 years $^{2,3}$, questioning the utility of short term outcomes to assess the long-term effect of treatment on disability progression.

Disease control is particularly relevant for aggressive $\mathrm{MS}^{4}$, characterized by accelerated accrual of irreversible disability. Intense immunosuppression followed by autologous hematopoietic stem cell transplantation (aHSCT) has been extensively explored as a treatment strategy for aggressive $\mathrm{MS}^{5-}$ 12. The rationale of aHSCT in MS is to eliminate self-reacting cell clones and to induce selftolerance through a profound renewal of the immune system ${ }^{13-16}$. To date, outcome assessment after aHSCT is limited to a short follow-up and it's still unclear whether aHSCT is able to induce longterm drug-free disease remission. The largest registry-based study on aHSCT in $\mathrm{MS}^{17}$ has reported that almost half of transplanted patients remained free from neurological progression in the following 5 years. Against this background, in Italy aHSCT has been extensively used for MS since $1996^{8}$. To determine whether aHSCT is able to prevent long-term disability worsening, we analyzed the outcomes in a large cohort of people with aggressive MS who underwent aHSCT for the treatment of MS in Italy.

\section{$\underline{\text { Methods }}$}

\section{Study Design}

This study was an observational, retrospective, multicenter cohort study on aHSCT for the treatment of MS, collecting data from MS patients transplanted in Italy from 1997 to 2019. 
52 In July 1998, five Italian neurologic teams, together with the Italian Cooperative Group for Bone

53 Marrow and Blood Transplantation (GITMO), initiated a phase I/II trial on the use of aHSCT in

$54 \mathrm{MS}^{18}$. Thereafter, other Italian MS centers developed local transplant programs for MS patients,

55 (mostly identical to those developed by the two leading haemato-neurological centers in Italy -

56 Florence and Genoa-). Although no formal guidelines on patients selection for aHSCT exist, all

57 treated patients had aggressive MS, characterized by the occurrence of severe relapses or MRI

58 inflammatory activity or accelerated accrual of neurological disability despite active treatment.

59 Patients were treated with aHSCT according to the European Group for Blood and Marrow

60 Transplantation (EBMT) guidelines, following the decision of the treating physician and approval

61 of the local Ethics Committee.

62 To be included in the present retrospective study, a minimum data set [consisting of age, MS 63 phenotype, expanded-disability-status-scale (EDSS) at baseline, information on the transplant 64 technology and at least 1 follow-up visit after transplant] was required. For the analysis of MRI 65 disease activity, only patients with yearly brain MRI records were considered.

66

Standard Protocol Approvals, Registrations, and Patient Consents

Written informed consent was obtained from all patients. All participants provided consent to use their medical history for publication. This retrospective study was approved by the ethical standards committee of the coordinating center (protocol number 61/08).

\section{Conditioning regimens and transplant care}

Peripheral hematopoietic stem cells (PBSCs) were mobilized with cyclophosphamide (CY) (4 or $2 \mathrm{~g} / \mathrm{m}^{2}$ iv) and filgrastim (5-10 $\mu \mathrm{g} / \mathrm{kg} /$ day $\left.\mathrm{sc}\right)$. PBSCs were collected with a leuko-apheresis procedure and an unmanipulated graft targeted to $3-8 \times 10^{6} \mathrm{CD} 34^{+}$cells $/ \mathrm{kg}$ was cryopreserved. Patients were transplanted using different conditioning regimens, according to center experience and preference: (i) BEAM+ATG regimen (74.8\%), which includes BCNU (carmustine, $300 \mathrm{mg} / \mathrm{m}^{2}$ 
78

79

80

81

82

83

84

85

86

87

88

89

90

91

92

93

94

95

96

97

98

at day -6$)$, cytosine-arabinoside $\left(200 \mathrm{mg} / \mathrm{m}^{2}\right)$ and etoposide $\left(200 \mathrm{mg} / \mathrm{m}^{2}\right)$ from day -5 to day -2 and melphalan $\left(140 \mathrm{mg} / \mathrm{m}^{2}\right)$ at day -1 , followed by rabbit anti-thymocyte globulin (ATG) (3.75-5 $\mathrm{mg} / \mathrm{kg} /$ day) at days +1 and +2 ; (ii) BEAM regimen as above described without rabbit ATG (4.8\%); (iii) FEAM regimen $(1.9 \%)$, substituting fotemustine $\left(150 \mathrm{mg} / \mathrm{m}^{2}\right.$ on days $\left.-7,-6\right)$ instead of BCNU in the BEAM regimen; (iv) CY+ATG regimen I (8.1\%), containing CY (60mg/kg at day -3 and -2$)$ followed by rabbit ATG $(3.75 \mathrm{mg} / \mathrm{kg} / \mathrm{d}$ at day +1 and +2); (v) CY+ATG regimen II (4.8\%), containing CY (50 mg/Kg/d at days -5 to day -2$)$ and rabbit ATG $(2.5 \mathrm{mg} / \mathrm{Kg} / \mathrm{d}$ at day -4 and -2$)$; (vi) Thiothepa+CY regimen (4.8\%), consisting of thiothepa $10 \mathrm{mg} / \mathrm{kg}$ for 5 days and CY $50 \mathrm{mg} / \mathrm{kg}$ at day -3 and -2 . One patient was transplanted with a conditioning regimen made of BCNU and melphalan $(0.5 \%)$ and one patient was transplanted with a conditioning regimen made of bortezomib, cyclophosphamide, dexamethasone and melphalan $(0.5 \%)$. Anti-herpetic and antipneumocistis jirovecii prophylaxes were performed with Acyclovir and SulphamethoxazolTrimetoprim, respectively, according to centers protocols. After aHSCT, patients did not receive immune-based therapies unless they experienced clinical relapse, new lesions on MRI, or EDSS progression, based on decision by the treating neurologist.

\section{Study endpoints}

The primary endpoint was to analyze the long-term 6 months-confirmed disability worsening as measured by EDSS. Secondary objectives were the evaluation of (i) the evolution of the EDSS scores after transplant, (ii) the occurrence of relapses, (iii) the occurrence of MRI inflammatory activity, (iv) the proportion of patients achieving "no-evidence-of-disease-activity (NEDA) status", a composite endpoint which includes the absence of clinical relapses, EDSS worsening and MRI inflammatory activity (v) the effect of the different conditioning regimens on long-term outcomes and (vi) the early transplant-related mortality. The analysis of the primary and the secondary endpoints generate class IV evidence of the long-term effects of transplant in people with aggressive MS. Disability worsening was defined as an increase of 1 point in the EDSS score (0.5 points if the 
baseline EDSS score was $\geq 5.5$ ) confirmed after 6 months. Baseline was defined as the last neurological assessment before the administration of mobilizing therapy. All relapses were clinically-assessed by treating neurologists. Follow-up for any component of NEDA score was not censored by earlier events so that each has an independent interpretation. MRI activity was defined as the presence of new/enlarging $\mathrm{T} 2$ lesions or $\mathrm{T} 1$ gadolinium-enhancing lesions detected by radiologists on routine follow up MRI. The baseline brain MRI (acquired within 3 months before the aHSCT procedure) was the pre-treatment reference scan for assessment of treatment failure and no re-baseline was performed. All deaths occurring in the first 100 days after transplant were reported and considered likely transplant-related ${ }^{19}$.

\section{Statistical analyses}

The probability of disability worsening-free survival, relapse-free survival, MRI-activity freesurvival and NEDA-3 status was calculated with the Kaplan-Meier estimator. Univariate and multivariate analyses assessing the association of disease- and treatment-related characteristics with survival endpoints were performed using Cox proportional hazards regression analysis models. Variables significantly associated with each outcome event on univariate analysis were included as covariates in the multivariate model. A linear mixed model with random intercept and random slope was carried out in order to detect changes in the EDSS scores before $v s$ after transplant. A twosided $p<0.05$ was used for statistical significance. All analyses were performed using SPSS 23 (IBM; version 23.0) and R software.

\section{$\underline{\text { Results }}$}

\section{Patients demographics and procedures}

Patients from 20 Italian MS centers who underwent transplant from 1997 to 2019 were identified $(n=210)$. Demographic, clinical and hematological characteristics of the study cohort are summarized in Table 1. Out of 210 patients, $n=196(93.3 \%)$ were eligible for the analysis of the 
130

131

132

133

134

135

136

137

138

139

140

141

142

143

144

145

146

147

148

149

150

151

152

153

154

155

primary endpoint. As for relapse occurrence, data were available for 198 (94.3\%) patients. Serial brain MRI radiology records were available for 167 (79.5\%) patients. At the time of transplant, 122 patients (58\%) had a relapsing-remitting (RR) phenotype of MS (RRMS), 86 patients (41\%) had secondary progressive (SP) MS and 2 patients (1\%) had primary-progressive MS. Data on previous treatment history is available for 175 patients (83.3\%). 118 patients had been exposed to interferonbeta, 55 to natalizumab, 54 to pulsed cyclophosphamide, 53 to mitoxantrone, 39 to azathioprine, 38 to glatiramer acetate, 29 to fingolimod, 7 to alemtuzumab and 6 to rituximab. Among patients with RRMS, those who were transplanted with the BEAMT+ATG protocol were older (34.0 years versus 28.3 years; $\mathrm{p}<0.0001)$, had longer disease duration $(10.3$ years versus 7.1 years; $\mathrm{p}=0.029)$ and had a shorter follow-up (5.1 years versus 7.2 years; $p=0.027$ ). Among patients with progressive MS, the BEAM+ATG subgroup had higher EDSS scores one year before transplant (median EDSS of 6 versus $5 ; \mathrm{p}=0.027$ ).

\section{Disability worsening-free survival and the evolution of neurological disability}

The probabilities of disability-worsening free survival for the entire study cohort and according to disease phenotype are reported in Figure $1 \mathrm{~A}$ and $1 \mathrm{~B}$, respectively. In the entire study cohort, disability worsening-free survival was $79.5 \%(72.0-86.6 \%)$ and $65.5 \%(55.3 \%-75.7 \%)$ at 5 and 10 years. The RRMS phenotype was associated with a reduced risk of disability worsening [HR $(95 \% \mathrm{CI})=0.46(0.24-0.86), \mathrm{p}=0.015]$, with disability worsening-free survival rates of $85.5 \%$ (76.9\%-94.1\%) at 5 years and $71.3 \%(57.8 \%-84.8 \%)$ at 10 years. In RRMS, a higher treatment exposure before aHSCT was associated with a higher risk of disability worsening [HR=1.57 (1.122.20), $\mathrm{p}=0.009$ ] (Table 2). Among patients with progressive MS, disability worsening-free survival was $71.0 \%(59.4 \%-82.6 \%)$ and $57.2 \%(41.8 \%-72.7 \%)$ at 5 and 10 years, respectively. A higher number of relapses in the year before aHSCT was associated with a lower risk of disability worsening $[\mathrm{HR}=0.56(0.34-0.92), \mathrm{p}=0.022]$. The use of the BEAM+ATG conditioning protocol did not influence the probabilities of disability worsening free-survivals. Progression-free survival in 
156

157

158

159

160

161

162

163

164

165

166

167

168

169

170

171

172

173

174

175

176

177

178

179

180

181

RRMS patients who were transplanted with the BEAM+ATG protocol was $81.9 \%(70.1 \%-93.7 \%)$ at 5 and 10 years.

Figure 1C shows the evolution of EDSS scores recorded after aHSCT in patients with RRMS and progressive MS. Among patients with RRMS, median EDSS scores significantly reduced after transplant over 10 years $[\mathrm{p}=0.001$, mean EDSS change per year $-0.09(95 \% \mathrm{CI}=-0.15$ to -0.04$)]$. EDSS stabilized in patients with progressive MS, with no significant increase over time $[\mathrm{p}=0.42$, mean EDSS change per year $=0.02(95 \% \mathrm{CI}=-0.03$ to 0.07$)]$.

\section{Secondary endpoints}

The probabilities of relapse-free survival, MRI inflammatory activity-free survival and NEDA-3 status are reported in Figure 2 (RRMS) and Figure 3 (progressive MS), according to the conditioning regimen used in the transplant technology. For RRMS patients, relapse-free survival was $78.1 \%(68.5 \%-87.7 \%)$ and $63.5 \%(49.4 \%-77.6 \%)$ at 5 and 10 years after aHSCT. In RRMS patients treated with the BEAM+ATG protocol, relapse-free survival was $86.4 \%(75.8 \%-97.0 \%)$ and $77.0 \%(61.5 \%-92.5 \%)$ at 5 and 10 years. The use of the BEAM+ATG conditioning protocol $[\mathrm{HR}=0.21(0.09-0.49), \mathrm{p}<0.0001]$ and an older age at transplant $[\mathrm{HR}=0.94(0.88-0.99), \mathrm{p}=0.034]$ were independently associated with a reduced risk of relapses (Table 2). Among patients with progressive MS, relapse-free survival was $88.3 \%(80.7 \%-96.0 \%)$ and $78.9 \%(63.4 \%-91.4 \%)$ at 5 and 10 years, respectively. The use of the BEAM+ATG conditioning protocol $[\mathrm{HR}=0.25(0.71$ 0.86), $\mathrm{p}=0.029$ ] was associated with a reduced risk of a relapse. In the entire study cohort, relapsefree survival was $82.9 \%(76.6 \%-89.2 \%)$ and $71.2 \%(61.8 \%-80.6 \%) 5$ and 10 years after aHSCT, respectively.

Probabilities for MRI inflammatory activity-free survival for patients with RRMS were 74.6\% $(63.2 \%-85.6 \%)$ at 5 years and $52.7 \%(35.6 \%-69.7 \%)$ after 10 years. When the BEAM+ATG was used, the MRI inflammatory activity-free survival was $82.0 \%(68.5 \%-95.5 \%)$ and $65.5 \%(45.3 \%$ $85.7 \%)$ at 5 and 10 years, respectively. The use of the BEAM+ATG conditioning regimen 
$182[\mathrm{HR}=0.24(0.11-0.54), \mathrm{p}=0.001]$ and an older age $[\mathrm{HR}=0.93 \quad(0.88-1.00), \mathrm{p}=0.041]$ were 183 independently associated with a reduced risk of MRI inflammatory activity after aHSCT (Table 2). 184 In the subgroup of patients with progressive MS, the MRI inflammatory activity-free survival was 185 at $84.0 \%(74.2 \%-93.8 \%)$ and $78.7 \%(65.2 \%-92.2 \%)$ at 5 and 10 years, respectively. The use of the 186 BEAM+ATG protocol was found to be associated with a higher probability of suppression of MRI 187 inflammatory activity $[\mathrm{HR}=0.28(0.08-1.00), \mathrm{p}=0.048]$. In the entire study cohort, the percentages 188 of patients free of MRI inflammatory activity were $78.7 \%(71.1 \%-86.3 \%)$ at 5 years and $64.3 \%$ $189 \quad(52.7 \%-75.9 \%)$ at 10 years.

190 For patients with RRMS, probabilities of achieving NEDA-3 status were $62.2 \%(50.6 \%-73.8 \%)$ at 5 191 years and $40.5 \%(30.0 \%-55.0 \%)$ at 10 years. In the subgroup of RRMS patients who underwent 192 aHSCT with the BEAM+ATG conditioning protocol, NEDA-3 status was achieved in $67.7 \%$ $193(53.2 \%-82.2 \%)$ and $54.9 \%(37.3 \%-72.5 \%)$ of patients at 5 and 10 years, respectively. In RRMS 194 patients, the use of the BEAM+ATG protocol $[\mathrm{HR}=0.27(0.14-0.50), \mathrm{p}<0.001]$ was associated with 195 a higher probability of maintaining NEDA-3 status (Table 2). In patients with progressive MS, 196 NEDA-3 status estimates were $50.8 \%(37.3 \%-64.3 \%)$ and $37.3 \%(22.8 \%-52.6 \%)$ at 5 and 10 years 197 respectively, and no baseline characteristics were found to be associated with the probability of 198 NEDA-3 status. In the entire study cohort, NEDA-3 status was achieved in $57.9 \%$ of patients $199(49.1 \%-66.7 \%)$ at 5 years and in $39.8 \%$ of patients $(29.2 \%-50.4 \%) 10$ years after aHSCT.

200 When comparing the BEAM+ATG conditioning regimen with the cyclophosphamide-based 201 protocols alone, we confirmed that, in patients with RRMS, the use of the BEAM+ATG was 202 associated with a lower risk of relapse [HR=0.12 (0.05-0.32), $\mathrm{p}<0.001]$, MRI inflammatory activity $203[\mathrm{HR}=0.18(0.07-0.48), \mathrm{p}=0.001]$ and with a higher probability of maintaining NEDA-3 status $204[\mathrm{HR}=0.18(0.09-0.38), \mathrm{p}<0.001]$ over the entire follow-up. In patients with progressive MS we did 205 not find any difference between BEAM+ATG and cyclophosphamide-based regimens on treatment 206 response. 
Thirty-two patients $(15.2 \%)$ started a new DMT after transplant. Median number of new DMTs was 1 (range 1-3, IQR 1-2), mean time to re-treatment was 3.7 years $(\mathrm{SD}=3.0)$ and median time was 2.08 years (range $=0.54-13.0$ ). DMTs initiated after aHSCT are listed in Table 3.

Three deaths occurred within 100 days following aHSCT (1.4\% of the entire study population).

Extensive data from these patients have already been reported ${ }^{8}$. Patient \#1, a 38 years-old secondary-progressive MS patient, developed pulmonary thrombo-embolism, which caused a syncope with head trauma 56 days after aHSCT. He was treated with fibrinolytic treatment and died 48 hours later after intracranial hemorrhage. Patient \#2, a 39 years-old RRMS patient, had engraftment failure and died 24 days after transplant due to an opportunistic infection caused by Actinomyces sp. Patient \#3, a 48 years-old RRMS patient, died 1 month after transplantation from a Wernicke's like encephalopathy. All deceased patients have been transplanted with the BEAM+ATG conditioning regimen. No transplant-related deaths occurred in patients transplanted after 2007.

\section{$\underline{\text { Discussion }}$}

Multiple sclerosis-related disability might take many years or decades to develop and very long follow-up periods are required in order to understand the role of treatments for MS.

We herein report the long-term outcomes in a large cohort of MS patients who underwent aHSCT in Italy in the last two decades, showing that $65.5 \%$ of patients were free of disability worsening 10 years after transplant, with a disability worsening-free survival greater than $70 \%$ in patients with RRMS. Our data extend previous studies at 5 years ${ }^{5-8,17}$, demonstrating that the effects of aHSCT persist for over a decade. These results are of particular relevance considering that patients treated with aHSCT were affected by extremely aggressive forms of MS, which is not the case in available randomized clinical trials. Of note, the 5-years progression-free survival rate in our cohort of RRMS (85.5\%) is higher than those reported with other highly active treatments for MS, such as natalizumab $^{20}$ and alemtuzumab ${ }^{21}$. In line with previous observations ${ }^{17}$, disability worsening-free 
survival in our cohort was higher in RRMS patients with lower treatment exposure, confirming the

234 notion that aHSCT should be performed early in the course of the disease.

235 Based on our data, patients with progressive MS still benefit from aHSCT. Indeed, we found a

236 disability worsening-free survival of $71 \%$ at 5 years, which was maintained in $57.2 \%$ of progressive

237 MS patients at 10 years. Although a control group was not available, such low rates of disability

238 worsening are an unexpected feature in progressive MS patients and deserve some consideration.

239 Accrual of neurological disability in progressive MS seems to be associated with

240 compartmentalized inflammation behind the blood-brain-barrier and recent data have demonstrated

241 that targeting inflammation within the CNS slow the course of progressive $\mathrm{MS}^{22,23}$. All the different

242 drugs used in the transplant technology share the ability to cross the blood-brain-barrier and to

243 penetrate in the CNS, where they can halt compartmentalized inflammation slowing neurological

244 deterioration. In line with this hypothesis, we found that a higher number of relapses in the year

245 before aHSCT, indicating residual ongoing CNS inflammation ${ }^{24}$, was associated with an increased

246 probability of disability worsening-free survival. We did not find any association between disease

247 duration and treatment effect. One possible explanation is that some patients of our cohort with

248 relatively long disease duration experienced dramatic disease exacerbations after withdrawal of

249 specific DMTs (especially natalizumab and fingolimod) and had excellent response to aHSCT,

250 possibly hiding the effect of disease duration on treatment response.

252 According to other independent groups ${ }^{5,11}$, we observed sustained EDSS reduction after transplant 253 in RRMS patients. When speculating on the possible effects of aHSCT in improving MS-related 254 disability, it's noteworthy that most of transplanted patients had experienced MS attacks right 255 before aHSCT and the reduction in disability could represent the expected gradual recovery from 256 relapses. In our cohort neurological improvement was sustained over 10 years and EDSS scores 257 continued to ameliorate beyond the first years following aHSCT, when recovery from relapses no 258 longer occurs, suggesting a robust effect of aHSCT in improving neurological status. It's arguable 
that after CNS inflammation is completely suppressed, endogenous structural and functional plasticity mechanisms eventually reemerge ${ }^{25}$, resulting in sustained clinical improvement.

The optimal intensity of the conditioning regimen for the treatment of MS remains an open question $^{26}$. This is the first study suggesting that the use of the BEAM+ATG conditioning regimen is independently associated with a reduced probability of relapses, MRI activity and NEDA-3 failure in patients with RRMS. Our results are in line with the evidence that a high-intensity, busulfan-based $^{6}$, but not a low-intensity cyclophosphamide-based ${ }^{27}$, conditioning regimen was able to completely abrogate MRI activity and clinical relapses. These results are also in line with the evidence that the bone marrow is the major site of memory helper $\mathrm{T}$ cells ${ }^{28}$ and memory plasma cells which are resistant to treatment with cyclophosphamide ${ }^{29}$ and that could be responsible for the maintenance of the autoimmune process over time. However, our results should be interpreted with caution because of the relatively small number of patients transplanted with cyclophosphamidebased regimens. Moreover, the cyclophosphamide protocols analyzed in this study are slightly different to the one used by Burt and colleagues ${ }^{11}$, preventing direct comparisons. Finally, it's important to note that in our work, as in published studies ${ }^{19}$, no transplant related mortality has been observed after cyclophosphamide-based aHSCT. We believe that, far from being a weakness, the distinct safety and efficacy profiles of the many conditioning regimens used in the transplant technology allow treatment tailoring on individual patient's disease course and profile risk, representing an advantage over available DMTs.

In this study we had the opportunity to analyze serial MRI records from 167 patients. Available long-term longitudinal MRI data after aHSCT are scarce and limited by small sample sizes ${ }^{6,30,31}$. In our cohort of RRMS patients treated with BEAM+ATG, $65.5 \%$ of patients were free of MRI inflammatory activity at 10 years. These results are quite impressive, considering that MRI activity is seen in $50-60 \%$ of patients treated with alemtuzumab ${ }^{21}$ and ocrelizumab ${ }^{32}$ in a typical 2-years 
301

follow-up. Similarly, percentages of NEDA-3 status at 5 and 10 years in the subgroup of patients with RRMS treated with BEAM+ATG (67.7\% and 54.9\% respectively) are higher than those reported in randomized clinical trials for available therapies ${ }^{26}$. However, these data should be interpreted with caution because patient populations and the follow-up schedules, as well as the use of a re-baseline MRI scan for MRI activity assessment, differ greatly between clinical studies.

\section{$\underline{\text { Limitations }}$}

Our work suffers from several methodological limitations. First, the EDSS raters were not blinded to treatment and this could have introduced some bias. However, the long-term design of this study has partially mitigated this measurement bias. Second, we had no information about the time between last clinical relapse and transplant start and we could not correct for this confounder when analyzing EDSS improvement over time, that can be thus overestimated. Third, clinical and MRI assessments were not systematically performed throughout the study. To overcome this bias, only patients with 6-months confirmed EDSS assessment and yearly MRI records were included in the analysis of treatment effects.

\section{Conclusions}

Findings from this study demonstrate that the benefits of aHSCT persist for over 10 years. Although patients with RRMS are those who benefit the most from transplant, aHSCT has been also shown to prevent disability worsening in a large proportion of patients with active progressive MS. The BEAM+ATG conditioning protocol, although associated with a higher transplant mortality rate, was associated with a more pronounced suppression of clinical relapses and MRI inflammatory activity, allowing complete disease control in a higher proportion of patients.

We suggest that aHSCT should be considered as a treatment strategy for MS not responding to conventional therapy. 
312 Autologous haematopoietic stem cell transplantation in Italy was partially funded and supported by

313 the Italian Multiple Sclerosis Foundation (FISM) with grants 2000/R/43, 2001/R/38 and 2002/R/36

314 to GLM. RS and CI activity was partially supported by a grant of Elena Pecci Research Fund. This

315 work was developed within the framework of the DINOGMI Department of Excellence of MIUR

316 2018-2022 (legge 232 del 2016).

317

\section{$318 \quad$ Data availability statement}

319 The data that support the findings of this study are available from the corresponding author upon

320 reasonable request.

321

322

323 Tables

Table 1. Demographic, disease-related and treatment-related characteristics.

$\begin{array}{lll}\text { Study } & \text { Relapsing-remitting MS }(\mathrm{n}=122) & \text { Progressive MS }(\mathrm{n}=88) \\ \text { Cohort } & & \\ (\mathrm{n}=210) & & \end{array}$

BEAM+ATG Other conditioning BEAM+ATG Other conditioning

$(n=90) \quad$ protocols $(n=32) \quad(n=67) \quad$ protocols $(n=21)$

\begin{tabular}{|c|c|c|c|c|c|}
\hline Age, mean (SD), y & $34.8(8.6)$ & $34.0(8.7)$ & $28.3(5.7)$ & $38.0(7.3)$ & $37.8(9.6)$ \\
\hline Females, n (\%) & $148(70.5)$ & $64(71.1)$ & $24(75.0)$ & $48(71.6)$ & $12(57.1)$ \\
\hline Disease duration, mean (SD), y & $11.0(6.7)$ & $10.3(6.7)$ & $7.1(3.5)$ & $13.2(6.7)$ & $13.2(7.2)$ \\
\hline EDSS, median (IQR) & $6.0(4.5-6.5)$ & $5.0(3.0-6.0)$ & $6(3.0-6.0)$ & $6.5(6.0-7.0)$ & $6.5(5.5-7.0)$ \\
\hline \multicolumn{6}{|l|}{ EDSS one year before aHSCT } \\
\hline Median (IQR) & $5.0(3.0-6.0)$ & $4(2.5-5.5)$ & $3.5(2.0-5.0)$ & $6(5.0-6.5)$ & $5.0(3.5-6.0)$ \\
\hline Missing, $n(\%)$ & $19(9.0)$ & $11(12.2)$ & $0(0)$ & $4(6.0)$ & $2(9.5)$ \\
\hline \multicolumn{6}{|l|}{$\begin{array}{l}\text { Delta EDSS in the year before } \\
\text { aHSCT }\end{array}$} \\
\hline Mean (SD) & $0.8(1.7)$ & $0.9(2.0)$ & $1.0(2.1)$ & $0.6(0.7)$ & $0.9(1.2)$ \\
\hline Missing, $n(\%)$ & $17(9.0)$ & $11(12.2)$ & $0(0)$ & $4(6.0)$ & $2(9.5)$ \\
\hline
\end{tabular}

\section{Number of relapses in the year} before aHSCT 


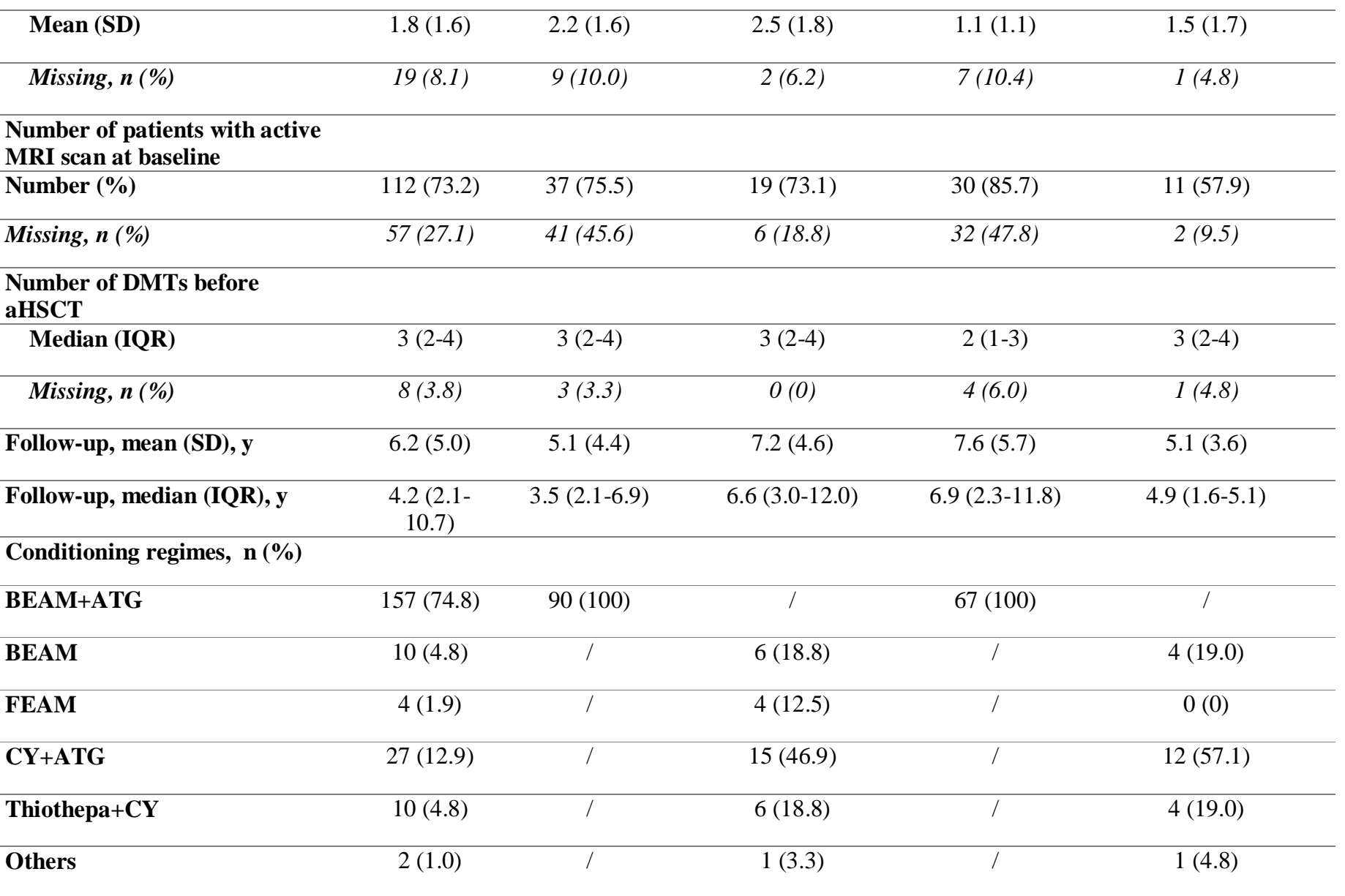

325

326 Table 2. Univariate and Multivariate Analyses of Factors Influencing Long-Term Outcomes.

\begin{tabular}{|c|c|c|c|c|c|c|c|c|c|c|c|c|}
\hline Relapsing-remitting MS & \multicolumn{2}{|c|}{$\begin{array}{l}\text { Disability } \\
\text { worsening }\end{array}$} & & \multicolumn{2}{|c|}{$\begin{array}{l}\text { Occurrence of a } \\
\text { relapse }\end{array}$} & & \multicolumn{2}{|c|}{$\begin{array}{c}\text { MRI- } \\
\text { inflammatory } \\
\text { activity }\end{array}$} & & \multicolumn{2}{|c|}{ NEDA-3 status } & \\
\hline & $\underset{\mathrm{n}}{\text { Eligible, }}$ & $\begin{array}{l}\mathrm{HR}(95 \% \\
\mathrm{CI})\end{array}$ & $\begin{array}{c}\mathrm{p} \\
\text { value }\end{array}$ & $\underset{\mathrm{n}}{\text { Eligible, }}$ & HR $(95 \% \mathrm{CI})$ & $\begin{array}{c}\mathrm{p} \\
\text { value }\end{array}$ & $\begin{array}{c}\text { Eligible, } \\
\mathrm{n}\end{array}$ & $\begin{array}{l}\mathrm{HR}(95 \% \\
\mathrm{CI})\end{array}$ & $\mathrm{p}$ value & $\begin{array}{c}\text { Eligible, } \\
\mathrm{n}\end{array}$ & $\begin{array}{l}\mathrm{HR}(95 \% \\
\mathrm{CI})\end{array}$ & $\begin{array}{c}\mathrm{p} \\
\text { value }\end{array}$ \\
\hline Age & 112 & $\begin{array}{l}1.05(1.00- \\
1.11)\end{array}$ & 0.054 & 113 & $\begin{array}{l}0.932(0.88- \\
0.98)\end{array}$ & $0.011 \#$ & 102 & $\begin{array}{l}0.93(0.88- \\
0.99)\end{array}$ & $0.015^{\wedge}$ & 106 & $\begin{array}{l}0.98(0.94- \\
1.02)\end{array}$ & $\begin{array}{c}0.97 \\
8\end{array}$ \\
\hline Disease duration & 111 & $\begin{array}{c}1.04(0.96- \\
1.11)\end{array}$ & 0.321 & 112 & $\begin{array}{l}0.96(0.89- \\
1.03)\end{array}$ & 0.281 & 101 & $\begin{array}{l}0.94(0.87- \\
1.01)\end{array}$ & 0.113 & 105 & $\begin{array}{l}0.98(0.93- \\
1.04)\end{array}$ & $\begin{array}{c}0.58 \\
8\end{array}$ \\
\hline Baseline EDSS score & 112 & $\begin{array}{l}0.96(0.77- \\
1.21)\end{array}$ & 0.747 & 113 & $\begin{array}{l}0.89(0.73- \\
1.10)\end{array}$ & 0.284 & 102 & $\begin{array}{l}0.91(0.75- \\
1.10)\end{array}$ & 0.33 & 106 & $\begin{array}{l}0.89(0.76- \\
1.04)\end{array}$ & $\begin{array}{c}0.16 \\
0\end{array}$ \\
\hline Number of treatments before aHSCT & 112 & $\begin{array}{l}1.57(1.12- \\
2.20)\end{array}$ & $\begin{array}{c}0.009 \\
0\end{array}$ & 112 & $\begin{array}{l}1.24(0.91- \\
1.67)\end{array}$ & 0.167 & 101 & $\begin{array}{l}1.15(0.87- \\
1.52)\end{array}$ & 0.326 & 105 & $\begin{array}{l}1.23(0.98- \\
1.54)\end{array}$ & $\begin{array}{c}0.07 \\
4\end{array}$ \\
\hline $\begin{array}{l}\text { Number of relapses in the year before } \\
\text { aHSCT }\end{array}$ & 104 & $\begin{array}{l}0.85(0.61- \\
1.18)\end{array}$ & 0.328 & 105 & $\begin{array}{l}1.04(0.82- \\
1.33)\end{array}$ & 0.725 & 96 & $\begin{array}{l}1.10(0.88- \\
1.38)\end{array}$ & 0.381 & 100 & $\begin{array}{l}0.95(0.78- \\
1.16)\end{array}$ & $\begin{array}{c}0.62 \\
7\end{array}$ \\
\hline $\begin{array}{l}\text { BEAM+ATG vs others conditioning } \\
\text { regimens }\end{array}$ & 112 & $\begin{array}{l}0.76(0.28- \\
2.06)\end{array}$ & 0.595 & 113 & $\begin{array}{l}0.19(0.08- \\
0.43)\end{array}$ & $\begin{array}{l}<0.00 \\
01 *\end{array}$ & 102 & $\begin{array}{l}0.22(0.10- \\
0.49)\end{array}$ & $<0.0001 \S$ & 106 & $\begin{array}{l}0.27(0.14- \\
0.50)\end{array}$ & $\begin{array}{l}<0.0 \\
001\end{array}$ \\
\hline Active baseline MRI scan & 70 & $\begin{array}{l}1.83(0.63- \\
5.29)\end{array}$ & 0.264 & 71 & $\begin{array}{l}1.29(0.52- \\
3.21)\end{array}$ & 0.587 & 62 & $\begin{array}{l}0.66(0.24- \\
1.81)\end{array}$ & 0.425 & 65 & $\begin{array}{l}1.69(0.85- \\
3.36)\end{array}$ & $\begin{array}{c}0.13 \\
5\end{array}$ \\
\hline \multicolumn{13}{|l|}{ Progressive MS } \\
\hline & $\underset{\mathrm{n}}{\text { Eligible, }}$ & $\begin{array}{l}\mathrm{HR}(95 \% \\
\mathrm{CI})\end{array}$ & $\begin{array}{c}\mathrm{p} \\
\text { value }\end{array}$ & $\begin{array}{c}\text { Eligible, } \\
\mathrm{n}\end{array}$ & $\mathrm{HR}(95 \% \mathrm{CI})$ & $\begin{array}{c}\mathrm{p} \\
\text { value }\end{array}$ & $\begin{array}{c}\text { Eligible, } \\
\mathrm{n}\end{array}$ & $\begin{array}{c}\mathrm{HR}(95 \% \\
\mathrm{CI})\end{array}$ & $\mathrm{p}$ value & $\begin{array}{c}\text { Eligible, } \\
\mathrm{n}\end{array}$ & $\begin{array}{c}\mathrm{HR}(95 \% \\
\mathrm{CI})\end{array}$ & $\begin{array}{c}\mathrm{p} \\
\text { value }\end{array}$ \\
\hline Age & 81 & $\begin{array}{c}1.01(0.96- \\
1.07)\end{array}$ & 0.658 & 82 & $\begin{array}{c}0.99(0.92- \\
1.09)\end{array}$ & 0.988 & 64 & $\begin{array}{c}0.97(0.89- \\
1.06)\end{array}$ & 0.525 & 67 & $\begin{array}{c}1.03(0.98- \\
1.09)\end{array}$ & $\begin{array}{c}0.20 \\
0\end{array}$ \\
\hline Disease duration & 81 & $\begin{array}{c}0.99(0.93- \\
1.06)\end{array}$ & 0.885 & 82 & $\begin{array}{c}1.03(0.93- \\
1.13)\end{array}$ & 0.584 & 64 & $\begin{array}{c}0.98(0.89- \\
1.09)\end{array}$ & 0.779 & 67 & $\begin{array}{c}1.02(0.96- \\
1.07)\end{array}$ & $\begin{array}{c}0.53 \\
6\end{array}$ \\
\hline Baseline EDSS score & 81 & $\begin{array}{c}0.91(0.59- \\
1.41)\end{array}$ & 0.671 & 82 & $\begin{array}{c}1.61(0.76- \\
3.44)\end{array}$ & 0.217 & 64 & $\begin{array}{c}1.49(0.65- \\
3.44)\end{array}$ & 0.345 & 67 & $\begin{array}{c}1.35(0.85- \\
2.12)\end{array}$ & $\begin{array}{c}0.20 \\
0\end{array}$ \\
\hline
\end{tabular}




\begin{tabular}{|c|c|c|c|c|c|c|c|c|c|c|c|c|}
\hline Number of treatments before aHSCT & 77 & $\begin{array}{l}0.96(0.71- \\
1.31)\end{array}$ & 0.812 & 78 & $\begin{array}{l}1.13(0.70- \\
1.83)\end{array}$ & 0.607 & 63 & $\begin{array}{c}1.07(0.63- \\
1.80)\end{array}$ & 0.806 & 66 & $\begin{array}{c}1.05(0.79- \\
1.38)\end{array}$ & $\begin{array}{c}0.72 \\
4\end{array}$ \\
\hline $\begin{array}{l}\text { Number of relapses in the year before } \\
\text { aHSCT }\end{array}$ & 75 & $\begin{array}{l}0.56(0.34- \\
0.92)\end{array}$ & 0.022 & 76 & $\begin{array}{l}1.13(0.72- \\
1.78)\end{array}$ & 0.590 & 63 & $\begin{array}{l}1.19(0.71- \\
1.98)\end{array}$ & 0.505 & 66 & $\begin{array}{l}0.71(0.49- \\
1.03)\end{array}$ & $\begin{array}{c}0.07 \\
6\end{array}$ \\
\hline $\begin{array}{l}\text { BEAM+ATG vs others conditioning } \\
\text { regimens }\end{array}$ & 81 & $\begin{array}{l}2.30(0.69- \\
7.74)\end{array}$ & 0.118 & 82 & $\begin{array}{l}0.25(0.71- \\
0.86)\end{array}$ & 0.029 & 64 & $\begin{array}{l}0.28(0.08- \\
1.00)\end{array}$ & 0.048 & 67 & $\begin{array}{l}0.99(0.42- \\
2.32)\end{array}$ & $\begin{array}{c}0.97 \\
5\end{array}$ \\
\hline Active baseline MRI scan & 42 & $\begin{array}{l}1.52(0.16- \\
14.4)\end{array}$ & 0.713 & 44 & $\begin{array}{l}0.69(0.08- \\
5.84)\end{array}$ & 0.731 & 37 & $\begin{array}{l}1.03(0.19- \\
5.43)\end{array}$ & 0.974 & 39 & $\begin{array}{l}0.86(0.24- \\
3.10)\end{array}$ & $\begin{array}{c}0.81 \\
7\end{array}$ \\
\hline
\end{tabular}

327

328

329 \# Multivariate analisis HR $(95 \% \mathrm{CI})=0.94(0.88-0.99), \mathrm{p}=0.034$

330

* Multivariate analisis HR $(95 \% \mathrm{CI})=0.21(0.09-0.49), \mathrm{p}<0.0001$

331

$\wedge$ Multivariate analisis HR $(95 \% \mathrm{CI})=0.93(0.88-1.00), \mathrm{p}=0.041$

332

$\S$ Multivariate analisis HR $(95 \% \mathrm{CI})=0.24(0.11-0.54), \mathrm{p}=0.001$

333

334

335 Table 3. Disease modifying therapies after aHSCT.

\begin{tabular}{|l|c|}
\hline \multicolumn{1}{|c|}{ Therapy name } & Number (\%) \\
\hline Natalizumab & $12(25.5)$ \\
\hline Fingolimod & $8(17.0)$ \\
\hline Dimethyl-fumarate & $7(14.9)$ \\
\hline Interferon beta 1a & $7(14.9)$ \\
\hline Glatiramer Acetate & $6(12.8)$ \\
\hline Ocrelizumab & $3(6.4)$ \\
\hline Cyclophosphamide & $2(4.3)$ \\
\hline Alemtuzumab & $1(2.1)$ \\
\hline Rituximab & $1(2.1)$ \\
\hline
\end{tabular}

336

337

338

339

340

341

342

343

344

345

346 
Figures' captions

Figure 1. Disability worsening-free survival and the evolution of the neurological disability.

Panel A shows the probabilities of disability worsening-free survival after aHSCT for the entire study cohort. Panel B shows disability worsening-free survival curves according to the MS phenotype. Panel $\mathrm{C}$ shows the evolution of the neurological disability in patients with RRMS and with progressive MS.

EDSS= expanded disability status scale; $M S=$ multiple sclerosis; $R R M S=$ relapsing-remitting multiple sclerosis.

Figure 2. Relapse-free survival, MRI inflammatory activity-free survival and No Evidence of Disease Activity (NEDA-3) status in patients with RRMS. Panels 2A, 2C and 2E show the probabilities of relapse-free survival, MRI inflammatory activity2F show the survival curves according to the conditioning regimen used within the transplant technology.

371 BEAM+ATG=carmustine, etoposide, cytarabine and melphalan plus rabbit anti-thymocyte 372 globulin; MRI= magnetic resonance imaging; NEDA-3= No Evidence of Disease Activity-3 
Figure 3. Relapse-free survival, MRI inflammatory activity-free survival and No Evidence of

Disease Activity (NEDA-3) status in patients with progressive MS.

376 Panels 3A, 3C and 3E show the probabilities of relapse-free survival, MRI inflammatory activity-

377 free survival and NEDA-3 percentages for patients with progressive MS. Panel 3B, 3D and 3F show

378 the survival curves according to the conditioning regimen used within the transplant technology. BEAM+ATG=carmustine, etoposide, cytarabine and melphalan plus rabbit anti-thymocyte globulin; MRI= magnetic resonance imaging; NEDA-3= No Evidence of Disease Activity-3

\section{$\underline{\text { Authors' statement }}$}

\begin{tabular}{|l|l|l|l|l|}
\hline Name & Degree & Location & Role & Contribution \\
\hline Giacomo Boffa & MD & University of & Author & design and \\
conceptualized \\
study; acquisition \\
of data; analyzed \\
Luca Massacesi & MD & the data; drafted \\
the manuscript.
\end{tabular}




\begin{tabular}{|c|c|c|c|c|}
\hline & & $\begin{array}{l}\text { Martino Hospital } \\
\text { IRCCS }\end{array}$ & & $\begin{array}{l}\text { study; acquisition } \\
\text { of data; revised the } \\
\text { manuscript for } \\
\text { intellectual } \\
\text { content. }\end{array}$ \\
\hline Alice Mariottini & MD & $\begin{array}{l}\text { University of } \\
\text { Florence, Careggi } \\
\text { University } \\
\text { Hospital }\end{array}$ & Author & acquisition of data \\
\hline $\begin{array}{l}\text { Marco } \\
\text { Capobianco }\end{array}$ & MD & $\begin{array}{l}\text { San Luigi } \\
\text { Gonzaga } \\
\text { Hospital, } \\
\text { Orbassano }\end{array}$ & Author & acquisition of data \\
\hline Lucia Moiola & $\mathrm{MD}$ & $\begin{array}{l}\text { San Raffaele } \\
\text { Hospita, Milan }\end{array}$ & Author & $\begin{array}{l}\text { acquisition of data; } \\
\text { revised the } \\
\text { manuscript for } \\
\text { intellectual content }\end{array}$ \\
\hline Maria Pia Amato & MD & $\begin{array}{l}\text { University of } \\
\text { Florence, IRCCS } \\
\text { Fondazione Don } \\
\text { Carlo Gnocchi }\end{array}$ & Author & $\begin{array}{l}\text { acquisition of data; } \\
\text { revised the } \\
\text { manuscript for } \\
\text { intellectual content }\end{array}$ \\
\hline $\begin{array}{l}\text { Salvatore } \\
\text { Cottone }\end{array}$ & MD & $\begin{array}{l}\text { Villa Sofia } \\
\text { Hospital, Palermo }\end{array}$ & Author & acquisition of data \\
\hline Francesca & $\mathrm{MD}$ & San Martino & Author & acquisition of data \\
\hline
\end{tabular}




\begin{tabular}{|c|c|c|c|c|}
\hline Gualandi & & $\begin{array}{l}\text { Hospital IRCCS, } \\
\text { Genoa }\end{array}$ & & \\
\hline Marco De Gobbi & MD & $\begin{array}{l}\text { San Luigi } \\
\text { Gonzaga } \\
\text { Hospital, } \\
\text { Orbassano }\end{array}$ & Author & $\begin{array}{l}\text { acquisition of data; } \\
\text { revised the } \\
\text { manuscript for } \\
\text { intellectual content }\end{array}$ \\
\hline Raffaella Greco & MD & $\begin{array}{l}\text { San Raffaele } \\
\text { Hospital, Milan }\end{array}$ & Author & $\begin{array}{l}\text { acquisition of data; } \\
\text { revised the } \\
\text { manuscript for } \\
\text { intellectual content }\end{array}$ \\
\hline Rosanna Scimè & MD & $\begin{array}{l}\text { Villa Sofia } \\
\text { Hospital, Palermo }\end{array}$ & Author & acquisition of data \\
\hline Jessica Frau & MD & $\begin{array}{l}\text { University of } \\
\text { Cagliari }\end{array}$ & Author & acquisition of data \\
\hline $\begin{array}{l}\text { Giovanni Bosco } \\
\text { Zimatore }\end{array}$ & MD & & Author & acquisition of data \\
\hline $\begin{array}{l}\text { Antonio } \\
\text { Bertolotto }\end{array}$ & MD & $\begin{array}{l}\text { San Luigi } \\
\text { Gonzaga } \\
\text { Hospital, } \\
\text { Orbassano }\end{array}$ & Author & acquisition of data \\
\hline Giancarlo Comi & $\mathrm{MD}$ & $\begin{array}{l}\text { San Raffaele } \\
\text { Hospital, Milan }\end{array}$ & Author & $\begin{array}{l}\text { acquisition of data; } \\
\text { revised the } \\
\text { manuscript for } \\
\text { intellectual content }\end{array}$ \\
\hline Antonio Uccelli & $\mathrm{MD}$ & University of & Author & acquisition of data; \\
\hline
\end{tabular}




\begin{tabular}{|c|c|c|c|c|}
\hline & & $\begin{array}{l}\text { Genoa, San } \\
\text { Martino Hospital } \\
\text { IRCCS }\end{array}$ & & $\begin{array}{l}\text { revised the } \\
\text { manuscript for } \\
\text { intellectual content }\end{array}$ \\
\hline Alessio Signori & $\mathrm{PhD}$ & $\begin{array}{l}\text { University of } \\
\text { Genoa }\end{array}$ & Author & analyzed the data \\
\hline $\begin{array}{l}\text { Emanuele } \\
\text { Angelucci }\end{array}$ & MD & $\begin{array}{l}\text { San Martino } \\
\text { Hospital IRCCS, } \\
\text { Genoa }\end{array}$ & Author & $\begin{array}{l}\text { acquisition of data; } \\
\text { revised the } \\
\text { manuscript for } \\
\text { intellectual content }\end{array}$ \\
\hline Chiara Innocenti & MD & $\begin{array}{l}\text { University of } \\
\text { Florence }\end{array}$ & Author & acquisition of data \\
\hline Fabio Ciceri & MD & $\begin{array}{l}\text { San Raffaele } \\
\text { Hospital, Milan }\end{array}$ & Author & $\begin{array}{l}\text { acquisition of data; } \\
\text { revised the } \\
\text { manuscript for } \\
\text { intellectual content }\end{array}$ \\
\hline $\begin{array}{l}\text { Anna Maria } \\
\text { Repice }\end{array}$ & $\mathrm{MD}$ & $\begin{array}{l}\text { University of } \\
\text { Florence, Careggi } \\
\text { University } \\
\text { Hospital }\end{array}$ & Author & acquisition of data \\
\hline $\begin{array}{l}\text { Maria Pia } \\
\text { Sormani }\end{array}$ & $\mathrm{PhD}$ & $\begin{array}{l}\text { University of } \\
\text { Genoa }\end{array}$ & Author & $\begin{array}{l}\text { analyzed the data; } \\
\text { revised the } \\
\text { manuscript for } \\
\text { intellectual } \\
\text { content. }\end{array}$ \\
\hline Riccardo & MD & University of & Author & design and \\
\hline
\end{tabular}




\begin{tabular}{|l|l|l|l|l|}
\hline Saccardi & & Florence & & $\begin{array}{l}\text { conceptualized } \\
\text { study; acquisition } \\
\text { of data; revised the } \\
\text { manuscript for }\end{array}$ \\
\hline Gianluigi & MD & University of & Author & content. \\
Mancardi & Genoa & design and \\
conceptualized \\
study; acquisition \\
of data; revised the \\
manuscript for \\
\end{tabular}

384

385

386

387

\section{Co-investigators statement}

\begin{tabular}{|l|l|l|l|l|}
\hline Name & Degree & Location & Role & Contribution \\
\hline M. Radaelli & MD & PXpa Giovanni & Co-investigator & acquisition of data \\
& & Bergamo & & \\
\hline Vincenzo Pavone & MD & Ospedale & Co-investigator & Acquisition of data \\
& & Cardinale & & \\
& & Giovanni Panico, & & \\
\hline C. Gasperini & MD & Tricase & & \\
\hline
\end{tabular}




\begin{tabular}{|c|c|c|c|c|}
\hline & & $\begin{array}{l}\text { Camillo- } \\
\text { Forlanini, Roma }\end{array}$ & & \\
\hline V. Zoli & MD & $\begin{array}{l}\text { Ospedale San } \\
\text { Camillo- } \\
\text { Forlanini, Roma }\end{array}$ & Co-investigator & acquisition of data \\
\hline L.M. Caniatti & MD & $\begin{array}{l}\text { Sant'Anna } \\
\text { Corona Hospital, } \\
\text { Ferrara }\end{array}$ & Co-investigator & acquisition of data \\
\hline F. Lanza & $\mathrm{MD}$ & $\begin{array}{l}\text { Santa Maria delle } \\
\text { Croci Hospital, } \\
\text { Ravenna }\end{array}$ & Co-investigator & acquisition of data \\
\hline S. Meletti & MD & $\begin{array}{l}\text { S.Agostino } \\
\text { Estense Hospital, } \\
\text { Modena }\end{array}$ & Co-investigator & acquisition of data \\
\hline M. Onofrj & MD & $\begin{array}{l}\text { University of } \\
\text { Chieti }\end{array}$ & Co-investigator & acquisition of data \\
\hline G. Meucci & MD & $\begin{array}{l}\text { USL6 Hospital, } \\
\text { Livorno }\end{array}$ & Co-investigator & acquisition of data \\
\hline E. Scarpini & MD & $\begin{array}{l}\text { University of } \\
\text { Milan }\end{array}$ & Co-investigator & acquisition of data \\
\hline S. Montepietra & MD & $\begin{array}{l}\text { Santa Maria } \\
\text { Nuova Hospital, } \\
\text { Reggio Emilia }\end{array}$ & Co-investigator & acquisition of data \\
\hline U. Aguglia & MD & $\begin{array}{l}\text { Bianchi } \\
\text { Melacrino }\end{array}$ & Co-investigator & acquisition of data \\
\hline
\end{tabular}




\begin{tabular}{|c|c|c|c|c|}
\hline & & $\begin{array}{l}\text { Morelli, Reggio } \\
\text { Calabria }\end{array}$ & & \\
\hline F. Granella & MD & $\begin{array}{l}\text { University of } \\
\text { Parma }\end{array}$ & Co-investigator & acquisition of data \\
\hline D. Guidetti & $\mathrm{MD}$ & $\begin{array}{l}\text { Guglielmo Da } \\
\text { Saliceto Hospital, } \\
\text { Piacenza }\end{array}$ & Co-investigator & acquisition of data \\
\hline L. Ruiz & MD & $\begin{array}{l}\text { SS.Antonio e } \\
\text { Biagio e Cesare } \\
\text { Arrigo Hospital, } \\
\text { Alessandria }\end{array}$ & Co-investigator & acquisition of data \\
\hline A.M. Raiola & MD & $\begin{array}{l}\text { San Martino } \\
\text { Hospital IRCCS, } \\
\text { Genoa }\end{array}$ & Co-investigator & acquisition of data \\
\hline R. Varaldo & MD & $\begin{array}{l}\text { San Martino } \\
\text { Hospital IRCCS, } \\
\text { Genoa }\end{array}$ & Co-investigator & acquisition of data \\
\hline E. Capello & MD & $\begin{array}{l}\text { San Martino } \\
\text { Hospital IRCCS, } \\
\text { Genoa }\end{array}$ & Co-investigator & acquisition of data \\
\hline E. Sbragia & MD & $\begin{array}{l}\text { University of } \\
\text { Genoa }\end{array}$ & Co-investigator & acquisition of data \\
\hline D. Currò & MD & $\begin{array}{l}\text { San Paolo } \\
\text { Hospital, Savona }\end{array}$ & Co-investigator & acquisition of data \\
\hline A. Barilaro & MD & Careggi & Co-investigator & acquisition of data \\
\hline
\end{tabular}




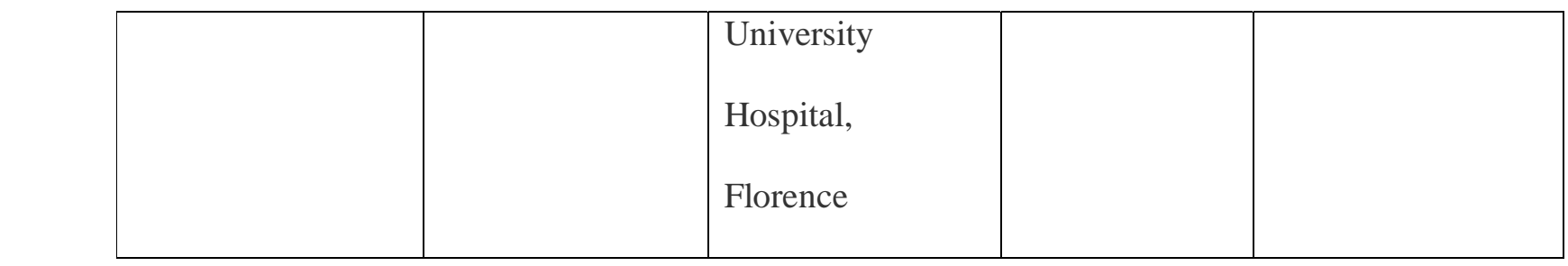

\section{$\underline{\text { References }}$}

394 1. Rotstein DL, Healy BC, Malik MT, Chitnis T, Weiner HL. Evaluation of No Evidence of 395 Disease Activity in a 7-Year Longitudinal Multiple Sclerosis Cohort. JAMA Neurol. 2015;72(2):152. doi:10.1001/jamaneurol.2014.3537

397 2. Cree BAC, Gourraud P-A, Oksenberg JR, et al. Long-term evolution of multiple sclerosis 398 disability in the treatment era. Ann Neurol. 2016;80(4):499-510. doi:10.1002/ana.24747

3. Cree BAC, Hollenbach JA, Bove R, et al. Silent progression in disease activity-free relapsing multiple sclerosis. Ann Neurol. 2019;85(5):653-666. doi:10.1002/ana.25463

4. Rush CA, MacLean HJ, Freedman MS. Aggressive multiple sclerosis: proposed definition 402 and treatment algorithm. Nat Rev Neurol. 2015;11(7):379-389. doi:10.1038/nrneurol.2015.85

5. Nash RA, Hutton GJ, Racke MK, et al. High-dose immunosuppressive therapy and autologous HCT for relapsing-remitting MS. Neurology. 2017;88(9):842-852.

405 doi:10.1212/WNL.0000000000003660

6. Atkins HL, Bowman M, Allan D, et al. Immunoablation and autologous haemopoietic stemcell transplantation for aggressive multiple sclerosis: a multicentre single-group phase 2 trial. Lancet. 2016;388(10044):576-585. doi:10.1016/S0140-6736(16)30169-6

7. Burman J, Iacobaeus E, Svenningsson A, et al. Autologous haematopoietic stem cell transplantation for aggressive multiple sclerosis: The Swedish experience. J Neurol Neurosurg Psychiatry. 2014;85(10):1116-1121. doi:10.1136/jnnp-2013-307207 
412 8. Mancardi GL, Sormani MP, Di Gioia M, et al. Autologous haematopoietic stem cell

413 transplantation with an intermediate intensity conditioning regimen in multiple sclerosis: The

414 Italian multi-centre experience. Mult Scler J. 2012;18(6):835-842.

$415 \quad$ doi: $10.1177 / 1352458511429320$

416 9. Mancardi GL, Sormani MP, Gualandi F, et al. Autologous hematopoietic stem cell

417 transplantation in multiple sclerosis: A phase II trial. Neurology. 2015;84(10):981-988.

$418 \quad$ doi:10.1212/WNL.0000000000001329

419 10. Moore JJ, Massey JC, Ford CD, et al. Prospective phase II clinical trial of autologous

420 haematopoietic stem cell transplant for treatment refractory multiple sclerosis. J Neurol Neurosurg Psychiatry. 2019;90(5):514-521. doi:10.1136/jnnp-2018-319446

422

423

424

425

426

427

428

429

430

431

432

433

434

435

436

437

11. Burt RK, Balabanov R, Burman J, et al. Effect of Nonmyeloablative Hematopoietic Stem Cell Transplantation vs Continued Disease-Modifying Therapy on Disease Progression in Patients With Relapsing-Remitting Multiple Sclerosis. Jama. 2019;321(2):165. doi:10.1001/jama.2018.18743

12. Kvistad SAS, Lehmann AK, Trovik LH, et al. Safety and efficacy of autologous hematopoietic stem cell transplantation for multiple sclerosis in Norway. Mult Scler J. December 2019:135245851989392. doi:10.1177/1352458519893926

13. Harris KM, Lim N, Lindau P, et al. Extensive intrathecal T cell renewal following hematopoietic transplantation for multiple sclerosis. JCI Insight. 2020;5(2). doi:10.1172/jci.insight.127655

14. Muraro PA, Robins H, Malhotra S, et al. T cell repertoire following autologous stem cell transplantation for multiple sclerosis. J Clin Invest. 2014;124(3):1168-1172. doi:10.1172/JCI71691

15. Sellner J, Rommer PS. Immunological consequences of "immune reconstitution therapy" in multiple sclerosis: A systematic review. Autoimmun Rev. 2020;19(4):102492. doi:10.1016/j.autrev.2020.102492 
438 16. Lünemann JD, Ruck T, Muraro PA, Bar'Or A, Wiendl H. Immune reconstitution therapies:

439 concepts for durable remission in multiple sclerosis. Nat Rev Neurol. 2019. doi:10.1038/s41582-019-0268-z

441

442

443

444

445

446

447

448

449

450

451

452

453

454

455

456

457

458

459

460

461

462

463

17. Muraro PA, Pasquini M, Atkins HL, et al. Long-term Outcomes After Autologous Hematopoietic Stem Cell Transplantation for Multiple Sclerosis. JAMA Neurol. 2017;74(4):459. doi:10.1001/jamaneurol.2016.5867

18. Mancardi GL, Saccardi R, Filippi M, et al. Autologous hematopoietic stem cell transplantation suppresses Gd-enhanced MRI activity in MS. Neurology. 2001;57(1):62-68. doi:10.1212/WNL.57.1.62

19. Sormani MP, Muraro PA, Schiavetti I, et al. Autologous hematopoietic stem cell transplantation in multiple sclerosis: A meta-analysis. Neurology. 2017;88(22):2115-2122. doi:10.1212/WNL.0000000000003987

20. Dekker I, Leurs CE, Hagens MHJ, et al. Long-term disease activity and disability progression in relapsing-remitting multiple sclerosis patients on natalizumab. Mult Scler Relat Disord. 2019;33:82-87. doi:10.1016/j.msard.2019.05.017

21. Coles AJ, Cohen JA, Fox EJ, et al. Alemtuzumab CARE-MS II 5-year follow-up. Neurology. 2017;89(11):1117-1126. doi:10.1212/WNL.0000000000004354

22. Kappos L, Bar-Or A, Cree BAC, et al. Siponimod versus placebo in secondary progressive multiple sclerosis (EXPAND): a double-blind, randomised, phase 3 study. Lancet. 2018;391(10127):1263-1273. doi:10.1016/S0140-6736(18)30475-6

23. Naegelin Y, Naegelin P, von Felten S, et al. Association of Rituximab Treatment With Disability Progression Among Patients With Secondary Progressive Multiple Sclerosis. JAMA Neurol. 2019:1-8. doi:10.1001/jamaneurol.2018.4239

24. Lublin FD, Reingold SC, Cohen JA, et al. Defining the clinical course of multiple sclerosis: The 2013 revisions. Neurology. 2014;83(3):278-286. doi:10.1212/WNL.0000000000000560

25. Di Filippo M, Sarchielli P, Picconi B, Calabresi P. Neuroinflammation and synaptic 
464

465

466

467

468

469

470

471

472

473

474

475

476

477

478

479

480

481

482

483

484

485

486

487

488

489

plasticity: theoretical basis for a novel, immune-centred, therapeutic approach to neurological disorders. Trends Pharmacol Sci. 2008;29(8):402-412. doi:10.1016/j.tips.2008.06.005

26. Muraro PA, Martin R, Mancardi GL, Nicholas R, Sormani MP, Saccardi R. Autologous haematopoietic stem cell transplantation for treatment of multiple sclerosis. Nat Rev Neurol. 2017;13(7):391-405. doi:10.1038/nrneurol.2017.81

27. Curro D, Vuolo L, Gualandi F, et al. Low intensity lympho-ablative regimen followed by autologous hematopoietic stem cell transplantation in severe forms of multiple sclerosis: A MRI-based clinical study. Mult Scler J. 2015;21(11):1423-1430. doi: $10.1177 / 1352458514564484$

28. Tokoyoda K, Zehentmeier S, Hegazy AN, et al. Professional Memory CD4+ T Lymphocytes Preferentially Reside and Rest in the Bone Marrow. Immunity. 2009;30(5):721-730. doi:10.1016/j.immuni.2009.03.015

29. Mumtaz IM, Hoyer BF, Panne D, et al. Bone marrow of NZB/W mice is the major site for plasma cells resistant to dexamethasone and cyclophosphamide: Implications for the treatment of autoimmunity. J Autoimmun. 2012;39(3):180-188.

doi:10.1016/j.jaut.2012.05.010

30. Mariottini A, Filippini S, Innocenti C, et al. Impact of autologous haematopoietic stem cell transplantation on disability and brain atrophy in secondary progressive multiple sclerosis. Mult Scler J. February 2020:135245852090239. doi:10.1177/1352458520902392

31. Fassas A, Kimiskidis VK, Sakellari I, et al. Long-term results of stem cell transplantation for MS: A single-center experience. Neurology. 2011;76(12):1066-1070. doi:10.1212/WNL.0b013e318211c537

32. Hauser SL, Bar-Or A, Comi G, et al. Ocrelizumab versus Interferon Beta-1a in Relapsing Multiple Sclerosis. N Engl J Med. 2017;376(3):221-234. doi:10.1056/NEJMoa1601277 
490

491

492 
A

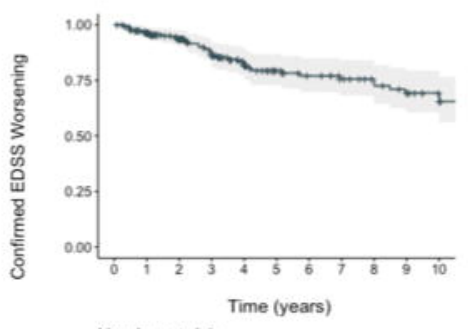

Number at risk
B

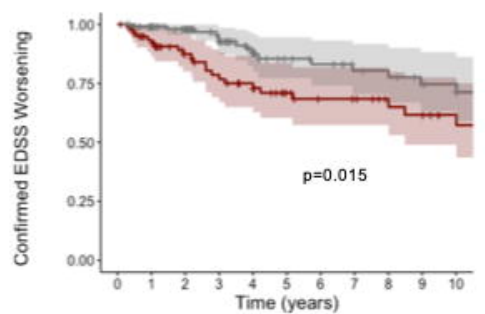

Number at risk
C

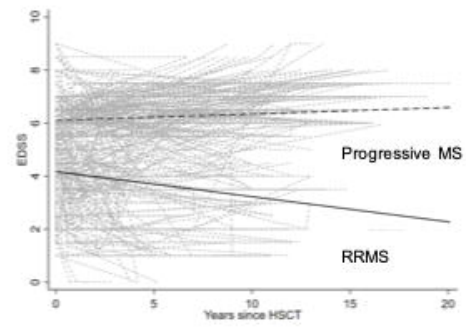

$\begin{array}{llllllllllll}\text { Overall population } & 196 & 170 & 143 & 112 & 88 & 67 & 60 & 54 & 49 & 43 & 36\end{array}$

$\begin{array}{llllllllllll}\text { Progressive MS } & 82 & 66 & 52 & 44 & 38 & 29 & 25 & 24 & 20 & 18 & 14\end{array}$

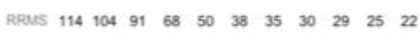


2A

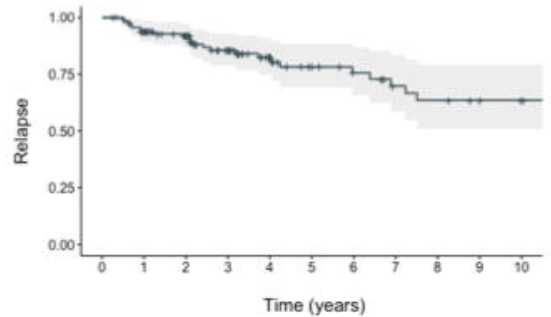

Number at risk

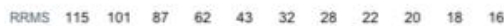

\section{C}

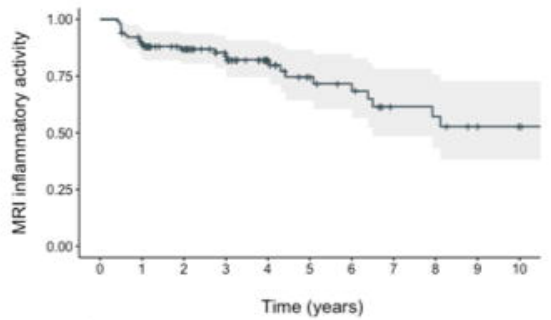

Number at risk

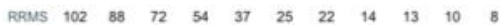

\section{E}

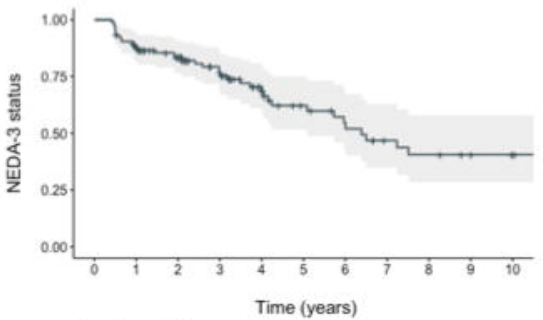

Number at risk

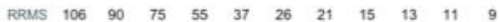

2B

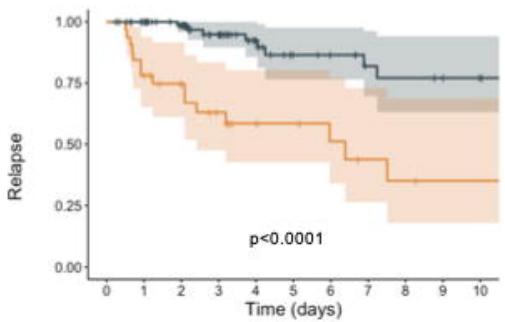

Number at risk

$\begin{array}{llllllllllll}\text { BEAM+ATG } & 83 & 76 & 67 & 48 & 33 & 23 & 21 & 17 & 16 & 15 & 13\end{array}$

$\begin{array}{lllllllllll}32 & 25 & 20 & 14 & 10 & 9 & 7 & 5 & 4 & 3 & 3\end{array}$

\section{D}

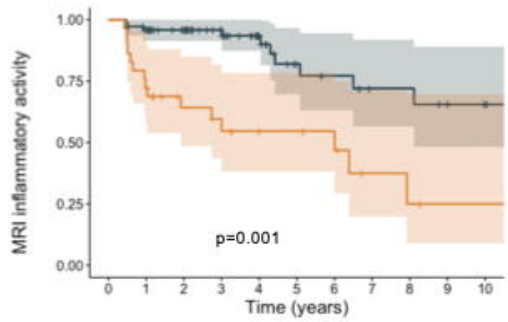

Number at risk

$\begin{array}{llllllllllll}\text { BEAM+ATG } & 73 & 67 & 58 & 42 & 28 & 17 & 15 & 11 & 11 & 9 & 7\end{array}$

$\begin{array}{llllllllllll}\text { Other Condtioning Regimens } & 29 & 21 & 14 & 12 & 9 & 8 & 7 & 3 & 2 & 1 & 1\end{array}$

\section{F}

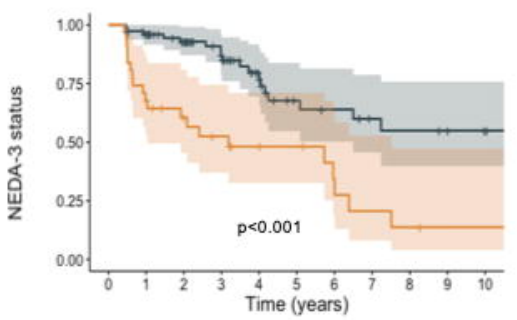

Number at risk

$\begin{array}{llllllllllll}B E A M+A T G & 75 & 69 & 59 & 43 & 28 & 18 & 16 & 12 & 11 & 10 & 8\end{array}$ 
3A

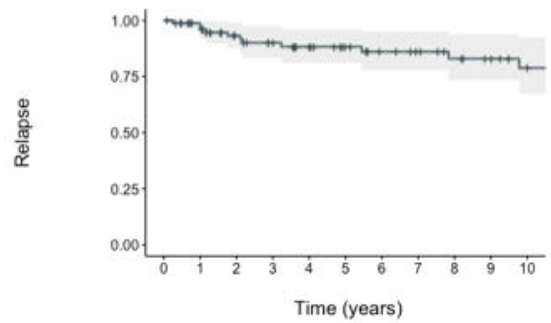

Number at risk

$\begin{array}{llllllllllll}\text { Progressive MS } & 83 & 73 & 60 & 53 & 47 & 40 & 34 & 31 & 27 & 24 & 18\end{array}$

$3 \mathrm{C}$

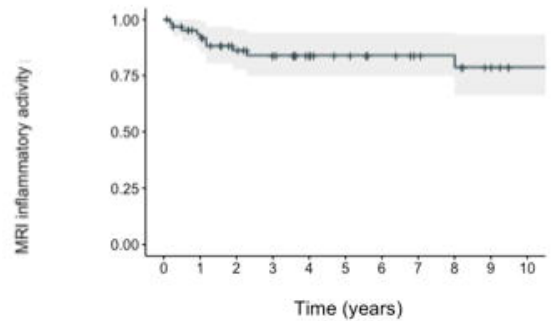

Number at risk

$\begin{array}{llllllllllll}\text { Progressive MS } & 65 & 54 & 43 & 37 & 28 & 24 & 20 & 17 & 16 & 12 & 8\end{array}$

\section{$3 E$}

离

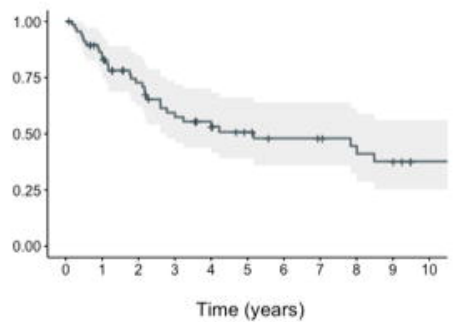

Number at risk
3B

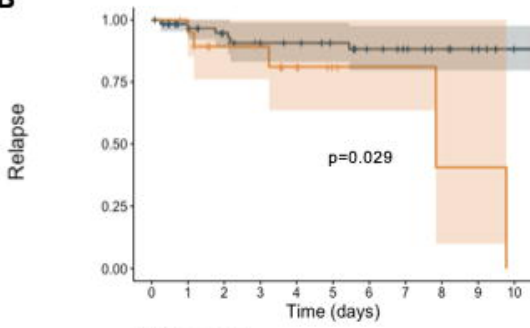

Number at risk

$\begin{array}{llllllllllll}B E A M+A T G & 63 & 54 & 47 & 42 & 40 & 37 & 32 & 29 & 26 & 23 & 18\end{array}$ $\begin{array}{llllllllllll}\text { Other Conditioning Regimens } & 20 & 19 & 13 & 11 & 7 & 3 & 2 & 2 & 1 & 1 & 0\end{array}$

3D

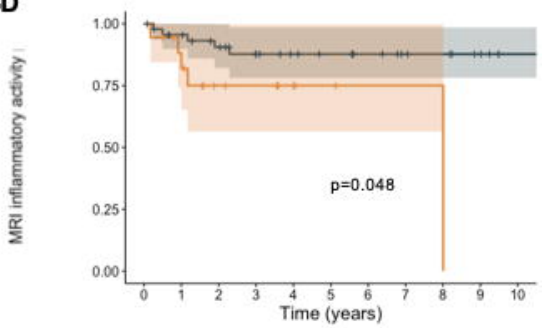

Number at risk

$\begin{array}{llllllllllll}\text { BEAM+ATG } & 47 & 40 & 35 & 30 & 24 & 22 & 19 & 16 & 15 & 12 & 8\end{array}$

$\begin{array}{llllllllllll}\text { Obier Contstoning Regiment } & 18 & 14 & 8 & 7 & 4 & 2 & 1 & 1 & 1 & 0 & 0\end{array}$

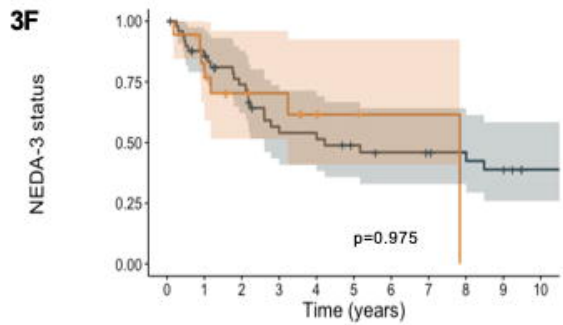

Number at risk

$\begin{array}{llllllllllll}\text { BEAM+ATG } & 50 & 39 & 31 & 22 & 21 & 17 & 15 & 14 & 13 & 11 & 7\end{array}$ 